\title{
Stereodivergent synthesis of jaspine B and its isomers using a carbohydrate-derived alkoxyallene as $\mathbf{C}_{3}$-building block
}

\author{
Volker M. Schmiedel, Stefano Stefani and Hans-Ulrich Reissig*
}

\author{
Full Research Paper \\ Address: \\ Institut für Chemie und Biochemie, Freie Universität Berlin, Takustr. 3, \\ D-14195 Berlin, Germany \\ Email: \\ Hans-Ulrich Reissig* - hreissig@chemie.fu-berlin.de \\ ${ }^{*}$ Corresponding author \\ Keywords: \\ chiral auxiliaries; gold catalysis; jaspine B; lithiated alkoxyallenes; \\ natural product synthesis; pachastrissamine; tetrahydrofurans
}

Open Access

\author{
Beilstein J. Org. Chem. 2013, 9, 2564-2569. \\ doi:10.3762/bjoc. 9.291 \\ Received: 27 August 2013 \\ Accepted: 28 October 2013 \\ Published: 19 November 2013 \\ This article is part of the Thematic Series "Natural products in synthesis \\ and biosynthesis".
}

Guest Editor: J. S. Dickschat

(C) 2013 Schmiedel et al; licensee Beilstein-Institut.

License and terms: see end of document.

\begin{abstract}
Herein we present the synthesis of the anhydrophytosphingosine jaspine B and three of its stereoisomers using a carbohydratederived alkoxyallene in order to obtain the products in enantiopure form. Key step of the reaction sequence is the addition of the lithiated alkoxyallene to pentadecanal, setting the configuration at the later C-2 of the ring system. This reaction step proceeds with moderate selectivity and therefore leads to a stereodivergent approach to the natural product and its enantiomer. The gold-catalyzed 5-endo-cyclization affords the corresponding dihydrofurans, which after separation, azidation of the enol ether moiety and two subsequent reduction steps give the natural product and its stereoisomers.
\end{abstract}

\section{Introduction}

Jaspine B, also known as pachastrissamine (1, Scheme 1), is an anhydrophytosphingosine derivative, isolated 2002 from the marine sponge Pachastrissa sp. by Higa et al. [1]. In 2003 Debitus et al. were able to extract this natural product from the marine sponge Jaspis sp. [2]. Jaspine B (1) comprises a densely functionalized tetrahydrofuran ring, bearing three contiguous $(2 S, 3 S, 4 S)$-configured stereogenic centers with a long alkyl chain at C-2 and a 1,2-amino alcohol moiety at C-3 and C-4. Due to its interesting structure and biological activities, for instance cytotoxicity and apoptosis promotion of several cancer cell lines [3-6] the synthesis of this natural product attracted the attention of many research groups resulting in more than 30 published syntheses up to now. Most frequently they are based on transformations of starting materials available from the "chiral pool", e.g. L-serine [7-18], or by asymmetric catalysis [19-25]. Several publications also focused on the synthesis of stereoisomers of the natural product $[4,12,16,17,19,26-28]$ because these compounds also showed comparable biological activities $[4,5]$.

During our current studies on the synthesis of highly functionalized heterocycles utilizing alkoxyallenes as versatile $\mathrm{C}_{3}$-build- 

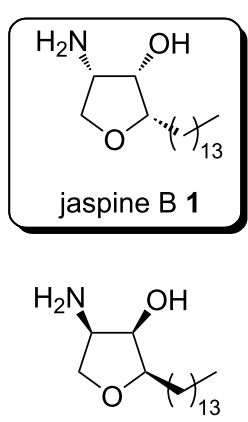

ent-jaspine B 3<smiles>CC(C)(C)[C@H]1OC[C@@H](N)[C@H]1O</smiles>

$(2 S, 3 R, 4 R)$-diastereomer 2<smiles>CC(C)C1OC[C@@H](N)[C@H]1O</smiles>

$(2 R, 3 S, 4 S)$-diastereomer 4
Scheme 1: Structure of jaspine B 1 and its stereoisomers 2-4.

ing blocks we chose jaspine B (1) as an attractive target [29-33]. Our approach to $\mathbf{1}$ is based on the addition of a lithiated alkoxyallene with a chiral auxiliary to pentadecanal as electrophile. This step will generate the first stereogenic center and install the $\mathrm{C}_{14}$-alkyl chain at the later $\mathrm{C}-2$ position of the natural product (Scheme 2). A subsequent 5-endo-cyclization of the resulting allenyl alcohols leads to a mixture of diastereomeric dihydrofurans, which can be separated by HPLC (only the $(S$ )enantiomer is depicted). This allows the synthesis of the natural product and its enantiomer by functionalization of both diastereomers. The cis-configured amino alcohol moiety at C-3 and $\mathrm{C}-4$ is installed by azidation and subsequent reduction steps leading to the final products. The presented strategy allows the preparation of jaspine $\mathrm{B}$, its enantiomer and two diastereomers, all of which are known for their biological activities (Scheme 2).

\section{Results and Discussion Synthesis of racemic jaspine B and its C-2- epimer}

Initial studies examined the feasibility of this planned approach for the generation of the functionalized tetrahydrofuran system. They were based on methoxyallene (5) and led to the preparation of the racemic natural product. Methoxyallene (5), which is easily prepared in two steps from propargyl alcohol in large scale [34], was deprotonated with $n$-BuLi and the generated lithiated methoxyallene was subsequently treated with pentadecanal (6). The resulting allenyl alcohol 7 was not sufficiently stable for purification and hence was directly used for the next cyclization step (Scheme 3). After a 5-endo-cyclization of 7 employing $\mathrm{KO} t$-Bu in DMSO dihydrofuran derivative 8 was obtained in $74 \%$ overall yield from $\mathbf{5}$. The strongly basic conditions as first described by Brandsma and Arens [35] used for the cyclization of 7 gave a higher yield than the attempted gold(I) catalysis (39\% overall yield), which might be due to the deactivation of the gold catalyst by impurities still present in the crude allenyl alcohol 7.
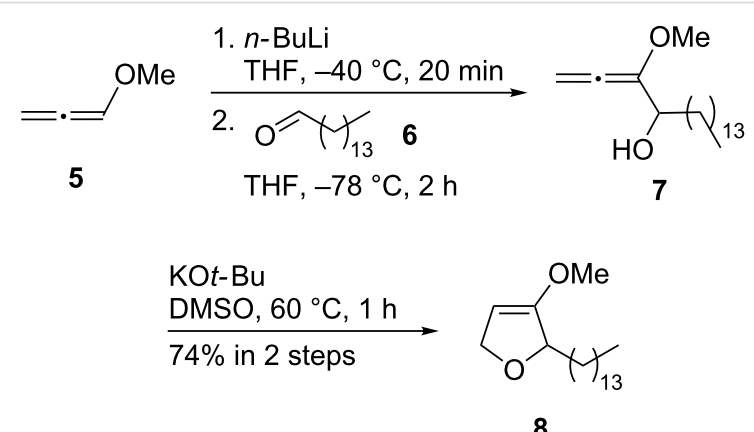

8

Scheme 3: Synthesis of racemic dihydrofuran 8.

Next, several methods for the introduction of the amino group were examined. We were very pleased to discover that the oxidative azidation [36] allowed a direct access to the corresponding $\alpha$-azidofuranones in one step. The two diastereomers of the azides were obtained in a 60:40 ratio. The subsequent reduction of the carbonyl group with L-selectride in THF furnished the $\alpha$-azidotetrahydrofuranols $\mathrm{rac}-\mathbf{9}$ and $\mathrm{rac}-\mathbf{1 0}$ in a satisfying yield of $62 \%$ over two steps (Scheme 4). Only the two diastereomers shown in Scheme 4 were isolated, whereas the two other possible isomers could not be detected. The obtained diastereoselectivity of the reduction is likely due to stereoelectronic effects of the $\alpha$-azido group overcoming the steric hindrance of the slim alkyl chain. We assume that in both diastereomers the azido group occupies a pseudoaxial position shielding this face of the furanone ring and therefore steers the

\footnotetext{
Scheme 2: Retrosynthetic analysis of jaspine $\mathrm{B}$ leading to pentadecanal and an alkoxyallene.
} 


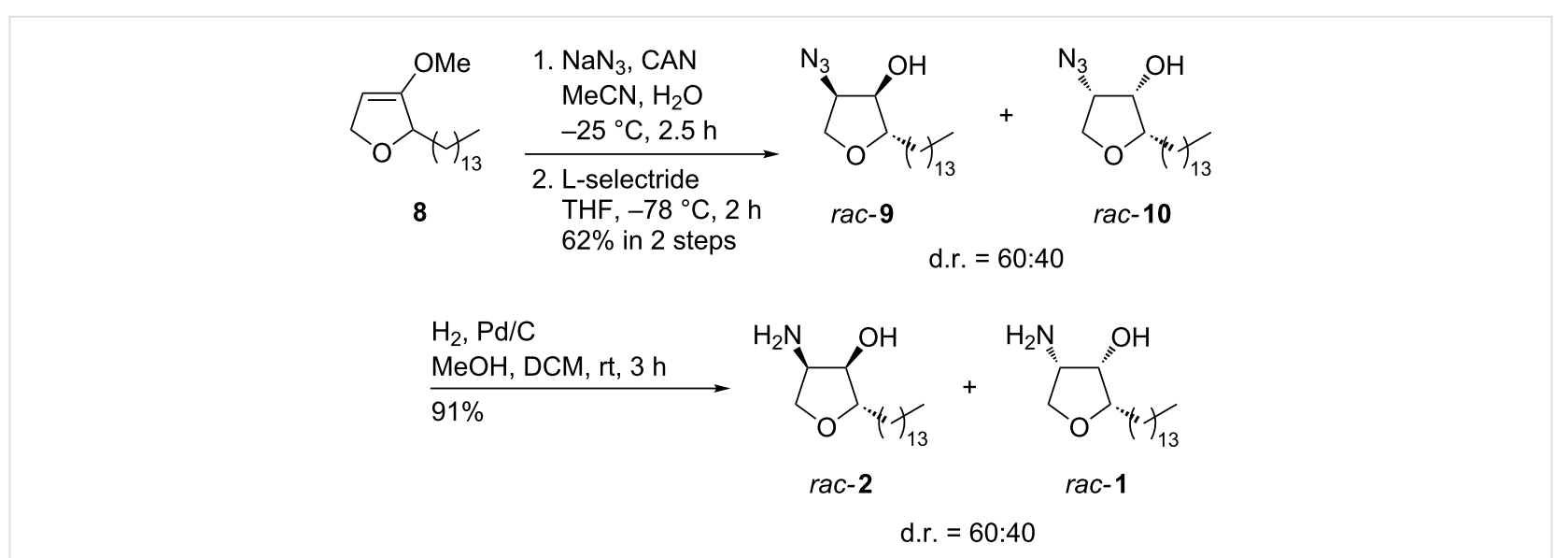

Scheme 4: Synthesis of racemic jaspine B rac-1 and its diastereomer rac-2.

hydride attack to the other side. Similar observations have been reported for the reduction of carbonyl compounds bearing an electronegative group in $\alpha$-position [37]. After palladiumcatalyzed hydrogenolysis of $\alpha$-azidotetrahydrofuranols $\mathrm{rac}-9$ and $r a c-10$ an inseparable mixture of racemic jaspine B ( $r a c-1)$ and its $\mathrm{C}$-2-epimer $\mathrm{rac}-\mathbf{2}$ was obtained. Hence the natural product and its diastereomer were obtained in five steps with a good overall yield of $42 \%$ with respect to aldehyde 6 . This result was very encouraging and we therefore started the preparation of the enantiopure natural product and its stereoisomers.

\section{Synthesis of enantiopure jaspine B using a carbohydrate-derived alkoxyallene}

Having established suitable conditions for the construction of the functionalized tetrahydrofuran core we focused our attention on the synthesis of enantiopure jaspine B (1). Earlier investigations by Goré [38] and our group already showed the feasibility of alkoxyallenes with carbohydrate-derived chiral auxiliaries for the synthesis of enantiopure natural products such as preussin [39] and anisomycin [40] or in hetero Diels-Alder reactions [41,42]. For the stereodivergent synthesis of both enantiomers of jaspine B (1), we chose diacetoneglucose-derived alkoxyallene 11, which is easily accessible on gram scale in two steps, starting from propargyl bromide (Scheme 5) [43]. Lithiation of $\mathbf{1 1}$ with $n$-BuLi and subsequent addition to pentadecanal (6) in analogous fashion to the synthesis of allenyl alcohol 7 led after column chromatography to a 57:43 mixture of the diastereomeric allenyl alcohols $\mathbf{1 2}$ and $\mathbf{1 3}$ in $57 \%$ yield. Base catalysis at higher temperatures, which was successfully used for the cyclization of 7, apparently induced partial decomposition of the auxiliary and led to only moderate yields (46\%) of dihydrofurans 14 and $\mathbf{1 5}$. Better yields of 14 and 15 were achieved under mild reaction conditions employing gold(I) catalysis [44], which after purification and separation afforded the expected products in $41 \%$ and $31 \%$ yields, respec- tively. The dihydrofurans $\mathbf{1 4}$ and $\mathbf{1 5}$ are more stable than the allenyl alcohols $\mathbf{1 2}$ and $\mathbf{1 3}$ and therefore allowed smooth separation by HPLC. At this point, the assignment of the absolute configuration at C-2 of $\mathbf{1 4}$ and $\mathbf{1 5}$ was only based on the comparison of reactions earlier studied in our group [45]. They could later be confirmed by comparison of the optical rotation of the final products with values reported in the literature.

Unfortunately, the attempted functionalization of dihydrofurans 14 and 15 by oxidative azidation (see above) only led to very low yields of the desired $\alpha$-azidotetrahydrofuranones (6\%). The conditions obviously cause decomposition of the auxiliary. As an alternative, the electrophilic bromination of $\mathbf{1 5}$ with NBS and the subsequent substitution with sodium azide furnished the desired diastereomeric $\alpha$-azidotetrahydrofuranones in a ratio comparable to that of the direct oxidative azidation of $\mathbf{8}$ (Scheme 6). Slightly higher selectivities in favor of the transconfigured $\alpha$-azidofuranone could be observed when the substitution reaction was run for a shorter period. This indicates that a (partial) epimerization at C-4 occurs under the reaction conditions employed. The diastereoselective reduction of the carbonyl group with L-selectride afforded the $\alpha$-azidotetrahydrofuranones 9 and 10 in 66\% yield over three steps. Subsequent hydrogenolysis of $\mathbf{9}$ and $\mathbf{1 0}$ afforded a mixture of jaspine B (1) and its $(2 S, 3 R, 4 R)$-diastereomer 2 in $91 \%$ yield.

Unfortunately, none of the diastereomeric mixtures obtained in all steps depicted in Scheme 6 were easily separable by HPLC, either due to the instability of the obtained compounds or the similar $R_{\mathrm{f}}$ values of the tetrahydrofuranol pairs $\mathbf{9 / 1 0}$ and $\mathbf{1 / 2}$. In order to solve this problem and to obtain pure stereoisomers, the $\alpha$-azidotetrahydrofuranols $\mathbf{9 / 1 0}$ were treated with benzyl chloroformate and converted into carbonates $\mathbf{1 6}$ and $\mathbf{1 7}$. This protection allowed the smooth separation of the diastereomers by simple flash chromatography, probably due to an enhanced 


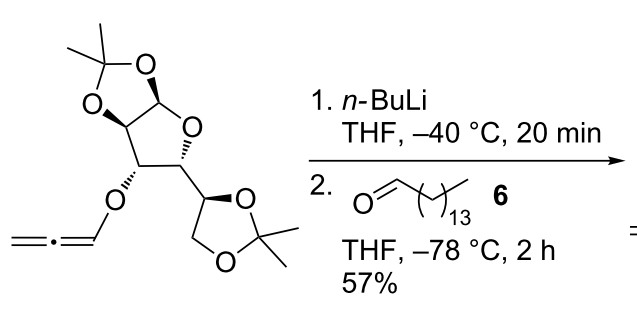

11

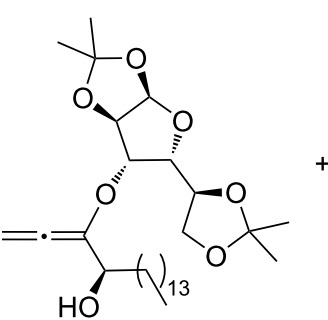

12<smiles>C=C=C(O[C@H]1[C@H]([C@H]2COC(C)(C)O2)OC2OC(C)(C)O[C@@H]21)C(O)C(C)C</smiles>

13

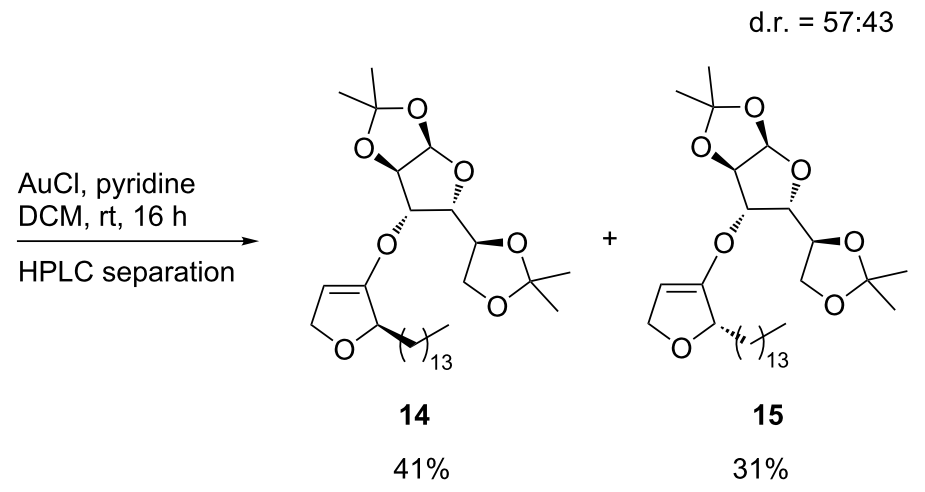

Scheme 5: Synthesis of dihydrofurans 14 and 15

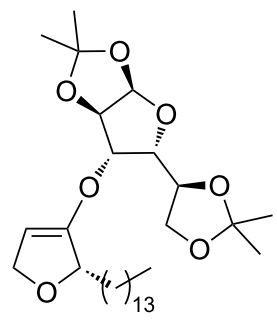

15

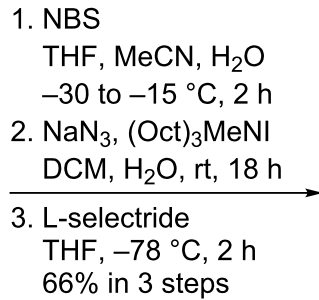

$66 \%$ in 3 steps

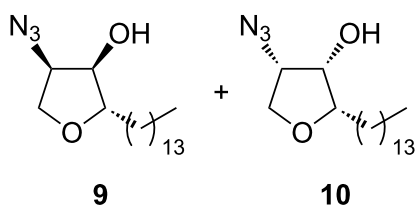

d.r. $=60: 40$

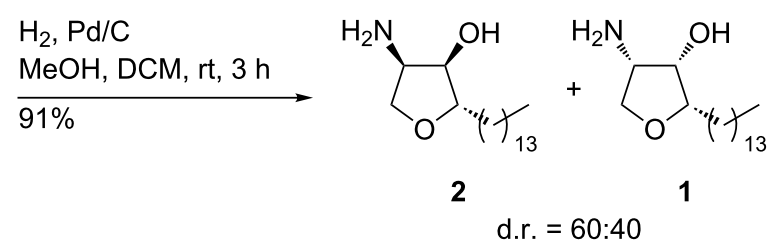

Scheme 6: Synthesis of jaspine B (1) and its $(2 S, 3 R, 4 R)$-diastereomer 2.

difference of dipole moments and hence $R_{\mathrm{f}}$ values of the two isomers (Scheme 7).

Final hydrogenolysis of the separated diastereomers $\mathbf{1 6}$ and $\mathbf{1 7}$ led to deprotection of the hydroxy group and simultaneous reduction of the azido group. Jaspine $\mathrm{B}(1)$ and its $(2 S, 3 R, 4 R)$ diastereomer 2 were each obtained in quantitative yield showing the expected optical rotations (Scheme 8).
Analogously to the reaction sequence leading to $\mathbf{1}$ and $\mathbf{2}$, the synthesis of ent-jaspine B (3) and the $(2 R, 3 S, 4 S)$-diastereomer 4 was also achieved in similar yields employing $(2 R)$-configured dihydrofuran $\mathbf{1 4}$ as starting material (Scheme 9).

\section{Conclusion}

We developed a stereodivergent synthesis of enantiopure jaspine B and three of its stereoisomers. Important knowledge 


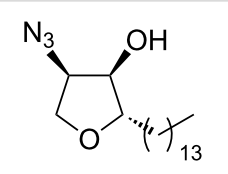

9 d.r. $=60: 40$
$\mathrm{NaH}, \mathrm{CbzCl}, \mathrm{DMAP}, \mathrm{Bu}_{4} \mathrm{NI}$ $\mathrm{DCM}, 0^{\circ} \mathrm{C}$ to rt, $18 \mathrm{~h}$

flash chromatography

10

Scheme 7: Protection and separation of the diastereomers.<smiles>[Y9]C1OCC(N)C1O[Na]</smiles>

17<smiles>CC(=O)OC1C(N)COC1[14C](C)(C)C</smiles>

16 $\underset{\begin{array}{l}\mathrm{HCM}, \mathrm{MeOH}, \mathrm{rt}, 6 \mathrm{~h} \\ \text { quant. }\end{array}}{\stackrel{\mathrm{H} d / \mathrm{C}}{\longrightarrow}}$ $\frac{\mathrm{H}_{2}, \mathrm{Pd} / \mathrm{C}}{\begin{array}{l}\mathrm{DCM}, \mathrm{MeOH}, \mathrm{rt}, 6 \mathrm{~h} \\ \text { quant. }\end{array}}$

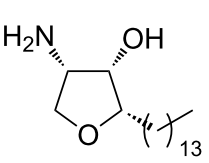

1

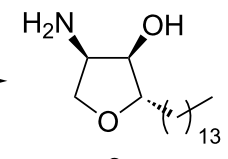

2
Scheme 8: Reduction of the separated diastereomers leading to jaspine B (1) and its diastereomer 2.<smiles>CC#CC1OCC(C2OC3OC(C)(C)OC3C2OC2=CCOC2C(C)(C)C)O1</smiles>

14
Scheme 9: Route to ent-jaspine B (3) and the $(2 R, 3 S, 4 S)$-diastereomer 4 .

could also be gained during the preparation of the racemic compounds. The carbohydrate-derived alkoxyallene $\mathbf{1 1}$ proved to be useful as a chiral $\mathrm{C}_{3}$-building block and allowed the synthesis of both enantiomers of the natural product in a fairly short manner (seven steps starting from the allene). The 5-endo-cyclization of allenyl alcohols $\mathbf{1 2}$ and $\mathbf{1 3}$ by gold catalysis afforded a separable mixture of diastereomeric dihydrofurans 14 and $\mathbf{1 5}$ in good yield. Subsequent functionalization using oxidative azidation, as shown for methoxy-substituted dihydrofuran $\mathbf{8}$, did not give the expected $\alpha$-azidotetrahydrofuranones in acceptable yields, but electrophilic bromination and subsequent substitution with sodium azide turned out to be a good alternative for the synthesis of the desired intermediates. Difficulties of the separation of the diastereomeric tetrahydrofuranols were successfully overcome by protection of the C-3 hydroxy group as carbonate, which enabled an easy chromatographic separation of the diastereomers and a global deprotection/reduc-

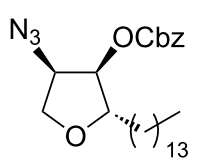

16

$53 \%$

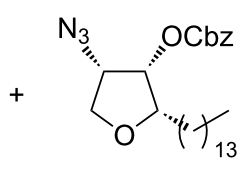

17

$40 \%$ tion leading to pure stereoisomers $\mathbf{1}$ and $\mathbf{2}$. Although the crucial steps of our approach to jaspine B are not stereoselective we found a simple access to the natural product and three of its stereoisomers, demonstrating again the usefulness of intermediates obtained from alkoxyallenes as $\mathrm{C}_{3}$-building block [46-50]. Employing other aldehydes instead of pentadecanal our straightforward route should also allow the synthesis of analogues of jaspine B.

\section{Supporting Information}

Experimental details and NMR spectra of all new products and the final compounds are available in the Supporting information.

\section{Supporting Information File 1}

Experimental procedures and analytical data and NMR spectra.

[http://www.beilstein-journals.org/bjoc/content/ supplementary/1860-5397-9-291-S1.pdf]

\section{Acknowledgements}

This work was generously supported by Bayer HealthCare. We also thank C. Groneberg for the HPLC separations, Dr. R. Zimmer for valuable discussions and help during the preparation of the manuscript as well as Prof. Dr. M. Christmann for useful suggestions.

\section{References}

1. Kuroda, I.; Musman, M.; Ohtani, I. I.; Ichiba, T.; Tanaka, J.; Gravalos, D. G.; Higa, T. J. Nat. Prod. 2002, 65, 1505-1506. doi:10.1021/np010659y

2. Ledroit, V.; Debitus, C.; Lavaud, C.; Massiot, G. Tetrahedron Lett. 2003, 44, 225-228. doi:10.1016/S0040-4039(02)02541-8

3. Salma, Y.; Lafont, E.; Therville, N.; Carpentier, S.; Bonnafé, M.-J.; Levade, T.; Génisson, Y.; Andrieu-Abadie, N. Biochem. Pharmacol. 2009, 78, 477-485. doi:10.1016/j.bcp.2009.05.002

4. Canals, D.; Mormeneo, D.; Fabriàs, G.; Llebaria, A.; Casas, J.; Delgado, A. Bioorg. Med. Chem. 2009, 17, 235-241. doi:10.1016/j.bmc.2008.11.026

5. Yoshimitsu, Y.; Oishi, S.; Miyagaki, J.; Inuki, S.; Ohno, H.; Fujii, N. Bioorg. Med. Chem. 2011, 19, 5402-5408. doi:10.1016/j.bmc.2011.07.061 
6. Yoo, H.; Lee, Y. S.; Lee, S.; Kim, S.; Kim, T.-Y. Phytother. Res. 2012 26, 1927-1933. doi:10.1002/ptr.4673

7. Abraham, E.; Davies, S. G.; Roberts, P. M.; Russell, A. J.; Thomson, J. E. Tetrahedron: Asymmetry 2008, 19, 1027-1047. doi:10.1016/j.tetasy.2008.04.017

8. Ichikawa, Y.; Matsunaga, K.; Masuda, T.; Kotsuki, H.; Nakano, K. Tetrahedron 2008, 64, 11313-11318. doi:10.1016/j.tet.2008.09.036

9. Inuki, S.; Yoshimitsu, Y.; Oishi, S.; Fujii, N.; Ohno, H. Org. Lett. 2009, 11, 4478-4481. doi:10.1021/ol901904w

10. Inuki, S.; Yoshimitsu, Y.; Oishi, S.; Fujii, N.; Ohno, H. J. Org. Chem. 2010, 75, 3831-3842. doi:10.1021/jo100544v

11. Yoshimitsu, Y.; Inuki, S.; Oishi, S.; Fujii, N.; Ohno, H. J. Org. Chem. 2010, 75, 3843-3846. doi:10.1021/jo1005284

12. Vichare, P.; Chattopadhyay, A. Tetrahedron: Asymmetry 2010, 21 , 1983-1987. doi:10.1016/j.tetasy.2010.06.024

13. Prasad, K. R.; Penchalaiah, K. Tetrahedron: Asymmetry 2011, 22 , 1400-1403. doi:10.1016/j.tetasy.2011.07.010

14. Passiniemi, M.; Koskinen, A. M. P. Org. Biomol. Chem. 2011, 9 , 1774-1783. doi:10.1039/c0ob00643b

15. Srinivas Rao, G.; Venkateswara Rao, B. Tetrahedron Lett. 2011, 52, 6076-6079. doi:10.1016/j.tetlet.2011.08.170

16. Zhao, M.-L.; Zhang, E.; Gao, J.; Zhang, Z.; Zhao, Y.-T.; Qu, W.; Liu, H.-M. Carbohydr. Res. 2012, 351, 126-129. doi:10.1016/j.carres.2012.01.013

17. Srinivas Rao, G.; Chandrasekhar, B.; Venkateswara Rao, B. Tetrahedron: Asymmetry 2012, 23, 564-569. doi:10.1016/j.tetasy.2012.04.009

18. Yoshimitsu, Y.; Miyagaki, J.; Oishi, S.; Fujii, N.; Ohno, H. Tetrahedron 2013, 69, 4211-4220. doi:10.1016/j.tet.2013.03.091

19. Enders, D.; Terteryan, V.; Palecek, J. Synthesis 2008, 2278-2282. doi:10.1055/s-2008-1067142

20. Urano, H.; Enomoto, M.; Kuwahara, S. Biosci., Biotechnol., Biochem. 2010, 74, 152-157. doi:10.1271/bbb.90670

21. Salma, Y.; Ballereau, S.; Maaliki, C.; Ladeira, S.; Andrieu-Abadie, N.; Génisson, Y. Org. Biomol. Chem. 2010, 8, 3227-3243. doi:10.1039/c004218h

22. Llaveria, J.; Díaz, Y.; Matheu, M. I.; Castillón, S. Eur. J. Org. Chem. 2011, 1514-1519. doi:10.1002/ejoc.201001477

23. Dhand, V.; Chang, S.; Britton, R. J. Org. Chem. 2013, 78, 8208-8213. doi:10.1021/j04013223

24. Santos, C.; Fabing, I.; Saffon, N.; Ballereau, S.; Génisson, Y. Tetrahedron 2013, 69, 7227-7233. doi:10.1016/j.tet.2013.06.091

25. Lin, C.-W.; Liu, S.-W.; Hou, D.-R. Org. Biomol. Chem. 2013, 11, 5292-5299. doi:10.1039/c3ob40797g

26. Reddipalli, G.; Venkataiah, M.; Mishra, M. K.; Fadnavis, N. W. Tetrahedron: Asymmetry 2009, 20, 1802-1805. doi:10.1016/j.tetasy.2009.07.004

27. Sánchez-Eleuterio, A.; Quintero, L.; Sartillo-Piscil, F. J. Org. Chem. 2011, 76, 5466-5471. doi:10.1021/jo200639t

28. Martinková, M.; Pomikalová, K.; Gonda, J.; Vilková, M. Tetrahedron 2013, 69, 8228-8244. doi:10.1016/j.tet.2013.07.028

29. Hormuth, S.; Reissig, H. U. J. Org. Chem. 1994, 59, 67-73. doi:10.1021/jo00080a013

30. Hormuth, S.; Schade, W.; Reissig, H.-U. Liebigs Ann. 1996, 2001-2006. doi:10.1002/jlac.199619961209

31. Brasholz, M.; Reissig, H.-U. Angew. Chem. 2007, 119, 1659-1662. doi:10.1002/ange.200604078

Angew. Chem. Int. Ed. 2007, 46, 1634-1637.

doi:10.1002/anie.200604078
32. Brasholz, M.; Reissig, H.-U. Eur. J. Org. Chem. 2009, 3595-3604. doi:10.1002/ejoc.200900450

33. Brasholz, M.; Dugovič, B.; Reissig, H.-U. Synthesis 2010, 3855-3864. doi:10.1055/s-0030-1258265

34. Hoff, S.; Brandsma, L.; Arens, J. F. Recl. Trav. Chim. Pays-Bas 1968, 87, 916-924. doi:10.1002/recl.19680870807

35. Hoff, S.; Brandsma, L.; Arens, J. F. Recl. Trav. Chim. Pays-Bas 1969, 88, 609-619. doi:10.1002/recl.19690880513

36. Magnus, P.; Barth, L. Tetrahedron 1995, 51, 11075-11086. doi:10.1016/0040-4020(95)00681-W

37. Rosenberg, R. E.; Abel, R. L.; Drake, M. D.; Fox, D. J.; Ignatz, K.; Kwiat, D. M.; Schaal, K. M.; Virkler, P. R. J. Org. Chem. 2001, 66, 1694-1700. doi:10.1021/jo0011787

38. Rochet, P.; Vatèle, J.-M.; Goré, J. Synthesis 1994, 795-799. doi:10.1055/s-1994-25577

39. Hausherr, A. Ph.D. Thesis, Freie Universität, Berlin, Germany, 2001.

40. Kaden, S.; Brockmann, M.; Reissig, H.-U. Helv. Chim. Acta 2005, 88, 1826-1838. doi:10.1002/hlca.200590143

41. Arnold, T.; Orschel, B.; Reissig, H.-U. Angew. Chem. 1992, 104, 1084-1086. doi:10.1002/ange.19921040833 Angew. Chem. Int. Ed. Engl. 1992, 31, 1033-1035. doi:10.1002/anie.199210331

42. Zimmer, R.; Orschel, B.; Scherer, S.; Reissig, H.-U. Synthesis 2002, 1553-1563. doi:10.1055/s-2002-33328

43. Hausherr, A.; Orschel, B.; Scherer, S.; Reissig, H.-U. Synthesis 2001, 1377-1385. doi:10.1055/s-2001-15225

44. Gockel, B.; Krause, N. Org. Lett. 2006, 8, 4485-4488. doi:10.1021/ol061669z

45. Sörgel, S. Ph.D. Thesis, Freie Universität, Berlin, Germany, 2006.

46. Brasholz, M.; Reissig, H.-U.; Zimmer, R. Acc. Chem. Res. 2009, 42, 45-56. doi:10.1021/ar800011h

47. Lechel, T.; Reissig, H.-U. Pure Appl. Chem. 2010, 82, 1835-1844. doi:10.1351/PAC-CON-09-09-06

48. Pfrengle, F.; Reissig, H.-U. Chem. Soc. Rev. 2010, 39, 549-557. doi:10.1039/b914356d

49. Bouché, L.; Reissig, H.-U. Pure Appl. Chem. 2012, 84, 23-36. doi:10.1351/PAC-CON-11-09-20

50. Zimmer, R. Synthesis 1993, 165-178. doi:10.1055/s-1993-25823

\section{License and Terms}

This is an Open Access article under the terms of the Creative Commons Attribution License (http://creativecommons.org/licenses/by/2.0), which permits unrestricted use, distribution, and reproduction in any medium, provided the original work is properly cited.

The license is subject to the Beilstein Journal of Organic Chemistry terms and conditions: (http://www.beilstein-journals.org/bjoc)

The definitive version of this article is the electronic one which can be found at:

doi:10.3762/bjoc.9.291 